\title{
Study on PPP Model from the Perspective of Game between Government and Enterprises
}

\author{
Wei KONG ${ }^{1, a,{ }^{*}}$ \\ ${ }^{1}$ School of Taxation, Jilin University of Finance and Economics, Changchun 130117, \\ China
}

a360093129@qq.com

Keywords: PPP, Management operation, Game between government and
enterprises.

\begin{abstract}
In recent years, the application of PPP model in China is in full swing; both the scale and the scope of the region have achieved amazing results, but also a lot of problems. The focus of the issue is the game between government and enterprise operation management in the PPP project. In the game, government is in a strong position, the government performance of consciousness is unsubstantial, and this weakened the enthusiasm of enterprises to participate in PPP projects. The social capital in the PPP project has a decisive effect on the quality of public goods supply. In the PPP project, how to realize the organic combination of the government and the market is the research target.
\end{abstract}

\section{Analysis of the Situation to Carry Out Descriptive PPP Projects}

Since the application of PPP mode in China, the number has been rising continuously, and the trend is more obvious since 2010. PPP project is playing an increasingly important role in the development of China's economy, and the government is optimistic about the future development of the PPP project. At the same time, the government's annual investment in PPP projects has increased year by year.From the point of view of the distribution of PPP projects, PPP projects are mainly concentrated in three areas of energy, water and sewage treatment, transportation. At the end of September 2016, the total number of PPP is 10471 projects, covering 19 areas, a total investment of 12 trillion and 460 billion yuan. The two batch of demonstration projects of the Ministry of finance, number of projects 232, with a total investment of 786 billion 630 million yuan. From the provinces and regions to carry out the situation: the eastern region in Shandong province to promote PPP projects up to 1030, the total amount of up to 1 trillion and 128 billion 209 million yuan, the coastal areas of the PPP project (only 1 less Shanghai municipal engineering PPP project, the amount of 1 billion 395 million yuan), the PPP project in Beijing although the amount is not much, but the average individual amount is higher (31 projects, investment of 179 billion 936 million yuan). The central and western regions in Tibet currently no PPP projects, the amount and the number of overall project PPP project are larger, Guizhou Province, a total of 1545, the total amount of 1 trillion and 192 billion 615 million yuan, China topped. In addition to the situation in Northeast Liaoning Province, Heilongjiang and Jilin, the number of PPP projects and the overall size of the project ranked behind. Northeast China has been in the traditional mode of investment and financing and local financing platform as a public project financing channels, the local government showed considerable attention and enthusiasm, but with the PPP development of the actual situation, is not ideal, compared to the central and western regions have a certain gap in the number of PPP projects, the amount of. 
The number and amount of project PPP project description can be concluded that the economically underdeveloped provinces and remote areas due to local financial level, with the limitations of the traditional financing mode, the local government for the investment and financing system innovation, PPP model to promote stronger willingness to. Less to carry out instead of higher level of economic development, abundant financial resources, financial liquidity in the PPP project, but the area within the scope of the strength of private capital once dabbled in related fields, the higher the amount of a single PPP project.

\section{PPP Failure Cases in China: an Analysis based on Game Theory}

At present, there are many problems in the operation of PPP projects in various regions of China, which are caused by many factors, such as system, rules, procedures and so on. It is shown in Table 1.

Table 1. The domestic PPP operating failure case overview

\begin{tabular}{|c|c|c|}
\hline $\begin{array}{l}\mathrm{Ca} \\
\mathrm{se}\end{array}$ & Project Name & Main Problems \\
\hline 1 & $\begin{array}{l}\text { Tianjin shuang } \\
\text { gang garbage } \\
\text { incineration } \\
\text { power plant }\end{array}$ & $\begin{array}{l}\text { Government to provide financial subsidies, but the number of subsidies } \\
\text { is not clearly defined, resulting in the risk of insufficient income item } \\
\text { company bear. At the same time, the lack of supervision of local } \\
\text { government led to the crisis of confidence, and the project site also } \\
\text { lacks the necessary hearing procedures, which lead to mass incidents. }\end{array}$ \\
\hline 2 & $\begin{array}{l}\text { Fujian Quanzhou } \\
\text { Citong Bridge }\end{array}$ & $\begin{array}{l}\text { The government considered in advance, the emergence of competitive } \\
\text { projects, lower return on investment. Late construction, repurchase } \\
\text { problems. Government signed a contract simple, rough, more difficult } \\
\text { to coordinate. }\end{array}$ \\
\hline 3 & $\begin{array}{l}\text { Hangzhou Bay } \\
\text { Bridge }\end{array}$ & $\begin{array}{l}\text { Government planning is not considered, the emergence of competitive } \\
\text { projects ,project funding constraints, private enterprises have to transfer } \\
\text { shares. Serious conflicts between contract and planning, that leads to } \\
\text { gloomier prospect. }\end{array}$ \\
\hline 4 & $\begin{array}{l}\text { Beijing Jing tong } \\
\text { highway }\end{array}$ & $\begin{array}{l}\text { The specification not thorough, adjacent competitive projects, resulting } \\
\text { in the lack of traffic, the risk of project income insufficient. }\end{array}$ \\
\hline 5 & $\begin{array}{l}\text { Shandong zhong } \\
\text { hua power } \\
\text { generation } \\
\text { project }\end{array}$ & $\begin{array}{l}\text { The government's lack of long-term consideration in the introduction of } \\
\text { the project, the fixed return commitment led to the dilemma of } \\
\text { cooperation between the two sides now. Government fees, revenue } \\
\text { reduction, the purchase of electricity operation agreement lost the basis } \\
\text { of institutional mechanisms to continue to implement. }\end{array}$ \\
\hline 6 & $\begin{array}{l}\text { Lanzhou Veolia } \\
\text { Water Supply } \\
\text { Project }\end{array}$ & $\begin{array}{l}\text { Inadequate investment, unable to maintain the normal operation of the } \\
\text { water supply system. Lack of technical facilities maintenance, resulting } \\
\text { in serious water pollution incident. The contract does not specify the } \\
\text { risk sharing mechanism. }\end{array}$ \\
\hline 7 & $\begin{array}{l}\text { Changchun Hui } \\
\text { Jin sewage } \\
\text { treatment project }\end{array}$ & $\begin{array}{l}\text { The municipal government abolished the franchise in February } 2003 \text {. } \\
\text { The foundation of cooperation between government and social capital. } \\
\text { Changchun water company sewage treatment fee arrears, resulting in } \\
\text { the project cannot continue to run. Eventually, the Changchun } \\
\text { municipal government in } 2005 \text { to repurchase the project. The negative } \\
\text { effects of the lack of commitment to the government, the domestic and } \\
\text { foreign water investment confidence has a significant blow. }\end{array}$ \\
\hline
\end{tabular}


Through the analysis of the above typical failure cases, the cause of the PPP project shelved or even the last to give up from the government and the market are. On the government level, at the beginning of the lack of strict contract contract to promote a lot of projects, led directly to the late binding, a strong position in the game of government potential, creating the government contract consciousness is weak, affecting the good application of PPP mode, the introduction of social capital to ensure the participation of social capital projects will benefit, but when the completion of infrastructure construction and operation and not according to the contract law, especially when there is great need to adjust the policy or government in the election, the government often prevarication, damage the legitimate rights and interests of private capital, finally let private capital prohibitive for PPP project. In the final analysis, China is lack of legal system in the field of PPP protection. From abroad, the successful application of PPP model in countries or regions have established a relatively sound legal system, so as to ensure that the PPP model can be effectively run. On the market level, the social capital involved in the PPP project, in the game with the government, there are barriers to access. The PPP model is applied to the construction of infrastructure, the government is open to private enterprises in the field of public goods construction, encourage private sector participation in the performance, but most companies really want to be difficult to get access to opportunities. Furthermore, the ability to participate in the private enterprise PPP project is uneven, at this stage of the PPP project access to the market mechanism is not standardized and sound, but also increase the operation of all aspects of the PPP project may be a problem. At the same time as the game process of government and social capital are involved in the financial, tax and other related parts, how to develop the system and the way of the new government, enterprise how to make full use of the relevant policy is a common challenge to the two.

\section{Suggestions on Improving the PPP Mode to Realize Benign Operation in China Speed Up the Legislative Process, Strengthen Legal Protection}

The sound and normative of the legal system plays an important role in the long run of PPP mode in our country. If there is no specification of the perfect legal system to ensure the legitimate rights and interests of social capital, will greatly weaken the enthusiasm of social capital to participate in the practice of PPP; at the same time, the social public and the government's rights and interests are not guaranteed, will cause damage to the public interest, public targets affected by the final PPP model is difficult to Chinese in the long run. First of all, through the establishment of a sound legal system can reduce the operating costs of the system. If there is a clear legal regulation of the rights and obligations of both the government and the social capital in every aspect of the PPP project, we can reduce the transaction costs and improve the efficiency of the PPP model. Secondly, the establishment of a sound legal system, can break the barriers to limit inequality, and promote market access equality, so that the practice of PPP model in our country more standardized, and thus achieve the interests of justice.

\section{Establish the Framework of PPP Project Organization Model, Supplemented by the Relevant Supporting Agencies}

The engineering construction headquarters is responsible for the construction of infrastructure projects in China has been the practice of the local government officials sent by the co-ordination of the management of the engineering construction 
headquarters. Such a responsibility system has the following problems: the first command is not the legal entity has the construction management right, finally does not assume any risk of decision-making; second command is only representative of the government, only the position in administrative management and command functions, cannot play on cooperation in various Fang Ping coordination, the role of supervision; the last command is only a temporary agency, disbanded at the end of the project construction period, the main part of the project quality in the subsequent stages of responsibility cannot be found. Learn from the experience of the United Kingdom and Japan, we should build a framework of the system, to achieve financing, consulting management, project supervision and other multi-dimensional layout.

\section{The Establishment of PPP Project Information Disclosure Mechanism to Ease the Information Asymmetry}

The implementation of operations of the PPP project, the investigation of the whole process to search a large number of data and the actual situation, the process of enterprise information acquisition departments are often inadequate, which requires the government to establish the information disclosure mechanism, from the initial PPP project promotion, to the actual operation, and then to the performance evaluation can be the platform issued by the information sharing so that the community can fully know the rational treatment. The government should set up the construction standards, legal system, management system and project development information collection, screening, analysis, summary and so on. The PPP project has a long cycle and slow recovery in earnings, most of the funds at the early stage of the project by the social capital investment and other characteristics, so the social capital compared with the government departments concerned to bear more risk of income uncertainty. Therefore, the social capital needs to consider all kinds of factors in order to participate in the project investment. Therefore, the government should provide a reasonable range of information within the purview of the project, so that the social capital side to make faster decisions reduce their wait and see attitude, firm determination to participate in the project. The private sector will be the PPP project construction, operation, maintenance and market changes timely announce, in order to facilitate the supervision of the government, from their own perspective but also conducive to the realization of public products of high quality, high quantity. In the process of PPP project cooperation, only the participants can understand each other's situation, in order to avoid the loss of efficiency, to play their greatest advantage.

\section{Acknowledgement}

This research was financially supported by Jilin provincial science and technology department soft science research project (20160418081FG), Jilin Provincial Department of education general project ([2016] seventy-first) ,Jilin Provincial Social Science Fund doctoral program (2016BS17).

\section{References}

[1] Scharle, P. PPP in Transport infrastruction Development as a social game, Innovation 10(2002), vol 15, No. 3.

[2] Information on http://www.cpppc.org/, 2016-04-30.

[3] Tony Saich, Providing Public Goods in Transitional China, Palgrave Macmillan (2008). 
[4] Faisal Al-Sharif and Ammar Kaka. PFI/PPP topic coverage in construction journals. Proceedings of the 20th Annual ARCOM Conf., Heriot Watt University, Edinburgh, Scotland, U.K., 2004(1):711-719. 